\title{
ECOLOGY AND MANAGEMENT OF ARTHROPOD PESTS OF POULTRY
}

\author{
R. C. Axtell and J. J. Arends \\ Department of Entomology, North Carolina State University, Raleigh, North Carolina \\ 27695
}

\section{PERSPECTIVES AND OVERVIEW}

The growth in poultry production worldwide has been striking in recent years. The developed countries now have $26 \%$ of the human population but produce $48 \%$ of the world's poultry and $67 \%$ of the world's eggs (131). Per capita consumption of poultry meat is increasing in the developed countries while consumption of red meats is static or declining (163). Economics plays a large role in these changes, since in developed countries the efficiency of feed conversion of poultry has been steadily increased through selective breeding and improved management so that a feed conversion ratio of 2.0 or less is now common (109). The marketing of improved breeds throughout the world is making poultry production more efficient in all countries. To meet the needs of the increasing human populations, poultry production will rapidly expand in underdeveloped countries. Production has been increasing worldwide for several years (163), and the increases have been in large operations, using high densities of animals, financed and managed by large companies. These man-made production systems present challenges and opportunities for arthropod management as a subsystem of the total production management system (13). The production management systems are highly structured and sophisticated, and under the control of the parent company ("integrator") who owns the feed mills, hatcheries, processing plants, transportation, and some poultry houses (primarily breeder flocks). The integrator contracts with individual producers who raise the poultry, with young birds and feed supplied by the integrator. The producer is paid on a per unit basis (number of eggs, weight of birds). The threat of arthropod pest outbreaks is serious; proper pest 
management programs are necessary to avoid economic losses. For further information on the variety of poultry pests and associated diseases, see Hofstad et al (79) and Williams et al (169), and for chemical control measures see Drummond et al (47).

This review focuses on the major arthropod pest problems in modern integrated poultry production and ignores the minor pest species known to occur in small "backyard" flocks. Worldwide in modern high-density poultry production facilities, the major arthropod pests are: $(a)$ ectoparasites: mites, lice, and bedbugs, and (b) habitat pests: litter beetles and filth flies (house fly and other species). Integrated arthropod pest management programs must address all of these pests. The major arthropod pest species of concern and the pest management strategies vary with the housing and production systems.

\section{HOUSING AND PRODUCTION SYSTEMS}

Modern poultry production uses fully integrated production techniques that allow for the production of a large number of eggs, or birds for meat, on a small amount of land. This change in management systems from low to high bird densities has completely changed the environment in which the birds are reared and the stressors that can alter growth and production. In these high density production systems, management of the arthropod pests is directly related to the type of product being produced (meat or eggs), housing type, feed and water equipment, manure disposal, and the environmental quality within the house. For each type of poultry produced, there are specific requirements for temperature, air quality and movement, feed, and housing for maximum production at the least cost. Pest management strategies must be compatible with the poultry management and production requirements.

The ecology of the arthropod pests is tied to the artificial environment in which they and the birds exist, and changes in the environment that affect arthropods can only be made if they are not detrimental to the birds. Because the environments of the various types of production facilities differ, the complex of arthropod pests differs among the systems. As examples, flies (the house fly and related filth flies) are a major problem in caged-layer and breeder houses but are rarely a problem in broiler facilities. Northern fowl mites are a problem in caged-layer and breeder flocks but are rare in broilers which are in a house for too short a time (about 8 weeks) for a detrimental mite population to develop.

Although the details vary to meet climatic and geographic needs, the facilities and techniques for modern poultry production are basically the same worldwide (for illustrations and descriptions of poultry housing see Refs. 14, 119 , and 123). 


\section{ECTOPARASITES}

The impact of arthropod ectoparasites of poultry involves the stressing of the bird, feeding on the bird, and/or vectoring of disease organisms. Pests that are not ectoparasites may lower the quality of the bird's environment and thereby cause stress to the birds.

\section{Stress}

In poultry, responses to stress are elevated levels of corticosteroids $(33,55)$. Freeman (55) stated that some of the consequences of increased levels of corticosteroids are: $(a)$ reduction in food consumption, $(b)$ decreased gonadal activities, $(c)$ cardiovascular changes, $(d)$ lower immunological reactions, and (e) increased susceptibility to disease. Stressors may cause only localized reactions (e.g. mosquito bites), and the bird will adapt to the stress or the stress may cause death (e.g. insect-vectored disease organisms). Arthropod ectoparasites of poultry would be "hostless" if the stress they placed upon the host were great enough to cause death.

In low stress environments, increased corticosteroid levels have been shown to increase resistance of birds to bacteria but to decrease their resistance to viruses and mycoplasma $(72,73)$. Birds with high levels of corticosteroid may have lower levels of northern fowl mites than do birds with low levels of corticosteroid $(74,75)$. However, birds can be genetically selected for corticosteroid level (27). Field observations of mite infestations indicate that the strain of bird is important in determining the level of infestation and the inherited levels of corticosterone can be more important than stressinduced levels (75).

Many stressors, in addition to arthropods, may affect poultry, including feed quality, environment, temperature, humidity, ammonia levels, light, social interactions, age, and strain and type of bird. Each production system has its own built-in stressors. The impact of the arthropod pest may be tempered or increased by the other stressors within the production system.

\section{Northern Fowl Mite}

The northern fowl mite, Ornithonyssus sylviarum, is an ectoparasite of domestic and wild birds throughout the world, although it may be replaced by O. bursa in tropical regions. It is the primary ectoparasite of chickens $(38,40$, $105,162)$. The mite is common on wild birds, which readily introduce it into poultry production facilities. The biology and control of the northern fowl mite have been reviewed by Lemke \& Kissam (96). The entire life cycle of the mites occurs on the host, with the eggs laid in masses at the base of the feathers, primarily in the vent area. Only two (protonymph and adult) of the 


\section{AXTELL \& ARENDS}

five life stages feed on the host. The life cycle is short ( 5 to 12 days), and large populations can develop rapidly on the birds. The mites can survive off the host for a week or more, and this ability enhances the chances for transmission (43).

Even though biosecurity is high in modern facilities, northern fowl mites continue to be a problem. In addition to movement of the mites by wild birds, the mites are carried on rodents and contaminated egg trays and flats. In a North Carolina breeder farm with birds infested with northern fowl mites, the egg crates were found to be infested. The crates delivered to a second farm after being emptied at the hatchery had an average of 19 mites per case (personal observation). While some authors consider that wild birds or domestic birds are the major means of mite dissemination (96), we believe that the main means of transmission from farm to farm is contaminated equipment (mostly egg flats, cases, and chicken crates) and people.

In a breeder flock, the roosters generally have higher populations of northern fowl mites than do the hens, and the roosters will spread the mites among the hens (96). In caged-layer houses, the hens caged alone or in pairs generally have higher mite infestations than do those housed at greater numbers per cage $(11,75)$. Consequently, in monitoring birds for mite infestations, the roosters in a brooder flock should be examined at a $2: 1$ ratio to the hens, and in caged-layer houses, preference should be given to examining the birds that occur one or two per cage. The mites are generally more abundant near the vent $(95,96)$ and spread to other locations (breast, thigh, back) as the populations increase. Mites tend to be more uniformly distributed over the entire body of roosters; this may be related to the contour of rooster feathers $(74,89)$. Some strains of birds as well as individual birds are resistant to the establishment of mites; the specific reasons are not clear $(29,96)$.

Attempts to examine the immune responses of chickens to northern fowl mites have given variable results $(29,41,96)$. Although the production of antibodies as a result of mite infestations have been detected, there is no way to use this information to quantify the level of infestation or predict its impact. A vaccine to give the birds immunity to mites has not been developed. Immunological research has been slowed by the lack of an efficient method for rearing the mites off the host $(34,35,54,96)$.

Economic losses due to northern fowl mites have been reported as decreased egg production, anemia, loss of condition, and death (96). Loss data about laying hens conflict $(39,97,106)$. Matthysse et al $(106)$ and DeVaney (39) found that losses may be greater if the birds are under other stresses at the same time that they suffer the mite infestation. Future research should take into account normal stress encountered in the production environment; the birds should not be placed in an "ideal" environment with no outside stress 
(such as inadequate air movement, poor quality feed and water, crowded cages). The genetics of commercial caged-layer hens has changed in recent years, and old data may not be relevant to today's genetic stocks.

In the competitive marketplace of poultry production, any increase in production costs is significant. Previous attempts to examine losses due to mites did not consider the feed consumption, though this is the single largest production cost. In breeder flocks, Arends et al (6) found that losses due to mites resulted both from fewer eggs per bird and from increased consumption that was equivalent to 1 to 6 cents per dozen eggs. In poultry production feeding levels are commonly increased if the production has decreased for unknown reasons. Augmenting feed per bird increases the production costs but does not overcome the impact of the mites (6). Eventually mite control is instituted and the cost of treatment incurred, while the delay in treatment has increased the possibility of mite transmission to more birds in the house and even to other houses.

Control of northern fowl mites in a modern integrated poultry production company requires changes in management procedures. Monitoring all of the flocks weekly or bimonthly is vital to detect infestations early. Prevention of movement of mites (by contaminated birds, people, or equipment) into a house (cultural control) is the most important method of control. Fumigation of egg flats and cases is effective (44) but inconvenient and costly. Wild birds should be excluded by screening, and rodents must be controlled in and around the poultry houses. Detailed records of all flocks should be maintained so that facilities with repeated mite infestations can be given special attention to prevent the spread of mites to other farms within a company.

Chemical control of northern fowl mites becomes necessary when these cultural measures fail. Since the risk of mites from a few birds in a house to the remainder of the birds is great, at least part of the birds must be treated as soon as any mites are found in the routine monitoring. No chemical feed additives are registered for poultry ectoparasite control, owing mainly to problems of residues in the meat and/or eggs $(4,40)$. The most effective treatment is with high pressure, high volume sprays, and this is very difficult. Most chemical "failures" are due to inadequate treatment of the birds. This may be due to inappropriate formulations, poor application equipment, and inability of the spray to reach the birds due to limited access in cage operations and the difficulties in herding the free birds in breeder houses. Mite resistance to chemicals has been reported for malathion, carbaryl, and stirofos $(12,47,96)$. Permethrin, a synthetic pyrethroid, is widely used for mite control, and to date there is no evidence of resistance (10). Due to the lack of ovicidal action and the chances that some birds were missed in the initial spraying of large flocks, respraying is advisable after 7-10 days. Dipping the birds (45) and feather clipping (42) give excellent control, but are impractical 


\section{AXTELL \& ARENDS}

and stressful to the birds. Insecticide-impregnated strips and tubing are effective in caged-layer houses $(76,77,88)$, but the cost and difficulties in their installation make them impractical.

\section{Lice}

The chicken body louse, Menacanthus stramineus, is the most common species of louse found in modern poultry production facilities $(4,14,40,105$, 162). The entire life cycle occurs on the host. The eggs are glued to the base of the feathers in dense clusters. The eggs hatch in 4-7 days into nymphs, which develop through three instars. The life cycle requires $2-3$ weeks. The data on economic losses caused by lice is conflicting, with reports of no losses $(156,166)$ and other reports $(37,48,70)$ of an economic effect from louse infestations. The birds used in the older trials were not the same genetically as today's birds, and so it is difficult to draw any conclusions relevant to current poultry production.

Lice are introduced into poultry houses by people, wild birds, infested equipment (especially egg flats), and rodents (46). After introduction, the lice spread from bird to bird by contact and the activities of rodents, people, and wild birds. Normally, mixed infestations of lice and other ectoparasites are not found, partly because the lice eat barbs and barbules (37); this makes the feathers less suitable for mites.

DeVaney (37) reported that louse infestations result in decreased hen weight, clutch size, and feed consumption, and that the older birds are at the time of infestation the more severe the impact. The reason for the age-related response is unclear; however, the older bird is declining in productivity, and the added stress of ectoparasites may accelerate this decline. In modern production, caged-layers are the group most likely to have a louse infestation (R. C. Axtell, J. J. Arends personal observation).

Control of lice requires regular weekly or bimonthly monitoring and cultural measures to prevent introductions, a process described above for northern fowl mites. It is essential to exclude wild birds, to control rodents, and to ensure that only clean equipment and personnel enter a house. If an infestation is detected, chemical treatment by high-pressure, high-volume spraying, like that described for northern fowl mite control, is necessary. In addition, before a previously infested house is restocked, it must be cleaned of all feathers that may contain egg masses and a residual insecticide applied to the structure. To eliminate lice established on a farm is difficult unless all houses are emptied of birds at the same time and thoroughly cleaned and sprayed. There are no reports of lice being resistant to insecticides. Although malathion, carbaryl, and stirofos are used for lice control, permethrin is most widely used because of its long-term effectiveness. 


\section{Chicken Mite}

The chicken mite, Dermanyssus gallinae, is also known as the red mite and roost mite. Like bedbugs, the chicken mite is on the bird only to feed (mostly at night) and spends the rest of the time in cracks and crevices in the cage structure. Its eggs are laid in the hiding places and hatch into a six-legged larvae in 2-3 days. The larvae molt into nymphs without feeding, and the two nymphal stages and the adult mites each feed on a bird. Adults are able to live off the host without feeding for up to 34 weeks. The chicken mite causes feeding lesions, most likely to be seen on the breast and lower legs of the birds. Economic losses due to chicken mites have not been quantified, but the mites can cause anemia, transmit diseases, lower production, and increase feed consumption $(90,173,174)$. These mites are most likely to be a problem in breeder houses.

Chicken mites are transmitted from house to house by the same means as northern fowl mites and lice, described above. Consequently, control requires cultural measures to prevent infestations. Because the mite spends most of its time off the host and the eggs are laid off the host, great attention must be given to the environment (i.e. the structure and equipment). When an infestation is detected, not only the birds, but also all of the structure and equipment must be sprayed, with particular attention to the slats and nest boxes in breeder houses. Spray application of the chemicals used for control of northern fowl mites and lice are also effective against chicken mites; there is no evidence of resistance (174).

\section{Bedbug}

The bedbug, Cimex lectularius, is a blood-feeder attacking humans and poultry worldwide. Its occurrence in modern poultry production facilities is sporadic, but an infestation of breeder houses is a serious problem. People working in the houses may carry the bedbugs back to their homes where infestations can become established. The bedbugs, like chicken mites, are on the birds only to feed (mostly at night). All stages of the bedbugs (eggs, nymphs, and adults) are found concealed in cracks and crevices in the house, especially in the slats and nest boxes in breeder houses. The eggs hatch in about 6 days, and each of the five nymphal instars takes a blood meal. The nymphs may withstand starvation for 70 days, and adults can live without feeding for up to 12 months. The feeding, which usually occurs at night, takes only 10 minutes for full engorgement. Since the bedbugs require harborage, the broiler breeder houses provide a suitable environment in the raised slats and the straw of wood shavings of the nest boxes. Birds raised on litter or in cages are rarely infested because protective sites are lacking. Although bed bugs have been reported as pests of poultry for more than 40 years, eco- 
nomic losses from them have not been quantified. Damage from bedbugs has been reported as allergic reactions of the growers, egg spots due to fecal deposits, lower production, and increased feed consumption (92). Bedbugs transmit various disease organisms in the laboratory (50), but epidemiological significance for transmission of any pathogen by bedbugs has not been demonstrated in the field. Because only a short time is spent on a host, the spread of bedbugs from farm to farm by wild birds or other hosts is minimal. The main means of dispersal are egg cases and flats transported by the integrators from infested farms to the hatchery and then to other farms for reuse (R. C. Axtell, J. J. Arends personal observation).

To monitor for bedbugs is difficult due to their hiding and nocturnal feeding. Evidence of a bedbug infestation are fecal spots (on posts, nest boxes, and other surfaces) and lesions on the breast and legs of the birds. Possible hiding places should be examined in the same manner as described above for chicken mites.

Control of bedbugs, like that of mites, is based on cultural measures taken to prevent introductions. If an infestation is found, thorough chemical treatment with special attention to the equipment and structure is required. As with control of chicken mite, control of bedbugs can be satisfactory only if all houses on a farm are cleaned and sprayed at the same time. The chemicals used for other ectoparasites are effective as sprays against bedbugs; permethrin is used frequently (143). There is no documented resistance to these chemicals.

\section{Ectoparasite Management}

The development and implementation of management programs for poultry ectoparasites is a continuing problem. The strategies and techniques must evolve as new strains of birds, new feeding systems, different housing, changed environmental control systems, and different production goals are adopted by the industry. The fundamental goals of the ectoparasite management program that must be met for the program to be successful in the field are: $(a)$ Ectoparasites must be controlled economically, and $(b)$ the program must fit into the everyday poultry management practices. The basic components of an ectoparasite management program are cultural control (exclusion of the arthropod), chemical control (spray applications of insecticides), and ectoparasite population monitoring.

Monitoring the ectoparasite populations in a poultry house and setting economic thresholds for treatment are important aspects of a pest management program. While evidence suggests that ectoparasites must reach certain levels before economic losses will occur, the data are limited and often conflicting. Usually the data do not include losses related to increased feed consumption. Consequently, we cannot presently define economic thresholds for poultry 
ectoparasites. Although in theory, treatment should be recommended only when the ectoparasite level reaches an economic threshold, in modern poultry production facilities, other concerns must be included in the decision of whether to treat. A major concern is the transport of the ectoparasites from one house to another, and from one farm to another, under the operation of one company. Although the ectoparasite population in one house may seem minor, in the total picture it may present a serious threat. The cost of treating one house or a part of a house must be weighed against the potential cost of treating many houses. Given current biosecurity practices in the poultry industry, the operators are not successful in isolating infested flocks and preventing the rapid expansion of ectoparasite populations to other flocks managed by the same company. If the ectoparasite population in a house is allowed to reach a certain level before treatment is used, the risk of ectoparasite movement is higher than if treatment is carried out earlier.

Consequently, the practical treatment level (rather that economic threshold) for poultry ectoparasites is the detection of a single parasite, i.e. treatment is recommended if any ectoparasites are detected by the monitoring program. If northern fowl mites or lice are found on caged birds, it may be necessary to treat only the sections of cages where ectoparasites are detected rather than all of the birds in the house. It is obviously easier to spray a few hundred birds in a few cages than to treat thousands of birds in an entire house or eventually in many houses if the infestation spreads. With breeder flocks, the entire infested house must be treated, but this is preferable to waiting and risking the need to treat many houses due to the spread of the ectoparasites.

Effective and practical chemical treatments for ectoparasite control in modern poultry operations are difficult. Liquid sprays are most widely used because dust formulations are difficult to apply, irritating to the birds, and often ineffective. Caged-layers are difficult to spray due to the closeness of the cages and limited access to the birds. It is impossible to direct the spray at the birds from several directions and coverage is spotty; some birds are even missed by the spray. Presently, spraying at $75-125$ psi with a solid stream (disc nozzle) from the front of the cages is most commonly recommended. Before spraying, the feed conveyors are emptied and the eggs retrieved. In breeder houses reaching all of the free-moving birds with a spray is difficult, and care must be taken to avoid excessive crowding of the birds, which may cause injury or death. Also, it is difficult to treat the nest boxes, under the slats, and in the cracks and crevices. At the time of spraying in breeder houses, the water and feed equipment should be raised to prevent contamination; fortunately that equipment is normally installed on cables so that it can be elevated readily. If any type of house is sprayed while birds are absent, spray should not be left standing in the feed equipment because subsequent rust will interfere with feed delivery and shorten the life of the equipment. 


\section{AXTELL \& ARENDS}

\section{HABITAT PESTS}

In confined poultry housing, a diversity of insects and mites will be found in the accumulated poultry manure (in caged-layer houses and beneath the slats in breeder houses) and litter (feces mixed with wood shavings or other plant materials in broiler and turkey grow-out houses and portions of breeder houses). These arthropods are mainly species of beetles (Coleoptera), flies (Diptera), and mesostigmatid mites $(2,9,80,94,103,127)$.

\section{Litter Beetles}

The two major pest species of litter beetles are Alphitobius diaperinus (Tenebrionidae), the lesser mealworm, and Dermestes maculatus (Dermestidae), the hide beetle. Other species in those genera may occur but apparently are rare.

LESSER MEALWORM The life history and bionomics of Alphitobius diaperinus have been described $(128,144,157,171)$. The eggs are laid in clusters in the manure or litter and develop through a variable number of larval instars (6 to 10 or more) requiring 40-60 days, depending upon the conditions. Pupation occurs in suitable portions of the manure or litter and in the soil beneath (the preferred site). Under conditions that are not fully understood, the late-stage larvae often move upward and pupate in the insulation in the building. The pupal stage lasts $7-12$ days, and the adults are long-lived (up to a year). Extremely large populations of all stages of these beetles can be found in some poultry houses, especially in the litter of broiler and turkey growout houses. The beetles often aggregate in areas of higher temperature, suitable moisture (especially around waterers), and nutrients (mainly spilled chicken feed). Consequently, greater numbers of insects may be found under and around feeders and waterers in broiler and turkey growout houses, and in areas of spilled feed in accumulated manure under caged-layer hens. In addition to feeding on chicken feed and other organic matter, the beetles (adults and late-instar larvae) will prey on smaller arthropods, including other lesser mealworm larvae; they also consume dead or moribund chicks.

The lesser mealworms are reservoirs for a wide variety of pathogens including several that are threats to poultry production (79). They harbor fungi (Aspergillus), bacteria (Escherichia, Salmonella, Bacillus, Streptococcus), and viruses causing leukosis (Marek's disease) and infectious bursitis (Gumboro disease). A variety of other viruses, including the agents causing fowlpox, Newcastle disease, and avian influenza, have been recovered from the beetles although other arthropods are considered to be more important vectors. Avian coccidosis, a major disease of poultry caused by protozoans 
(Eimeria spp.) is a poor survivor in poultry litter but survives as oocysts ingested by beetles which may then be ingested by the birds (133). The cysticercoids of helminths (Choanotaenia and Raillietina) which affect poultry have been recovered from $A$. diaperinus demonstrating its role as an intermediate host $(51,71)$.

In addition to the potential for spreading poultry disease pathogens, the lesser mealworms are detrimental to the poultry by providing an alternate food for the birds that may result in lesser weight gains compared to those of birds feeding normally on the nutrient-balanced feed. It has been suggested that the insect may cause lesions on the birds (22), and the scratching activity of the birds seeking the beetles in the litter may increase the susceptibilities of the birds to disease agents, owing to the irritation of the respiratory tract from the resulting dust (103). Humans may become allergic to A. diaperinus (145).

For modern poultry production facilities, the most serious impact of $A$. diaperinus is the structural damage $(84,96 \mathrm{a}, 120,142,161,165)$. The migration of the beetle larvae into the insulation for pupation results in extensive damage, to the extent that the insulation must be replaced after a few years. All types of insulation (especially polystyrene and polyisocyanurate) are damaged. Some tunneling into soft wood may occur. The loss of insulating value due to the holes and tunnels results in greater heating costs as well as lowered feed conversion efficiency of the birds due to the lack of adequate temperature control in the houses. Although adult beetles are found in the insulation, most of the damage is from larvae that have migrated there and pupated. Some adults will move into the holes caused by the larvae and use the insulation as an oviposition site. This problem is greatest in broiler and turkey growout houses because of the proximity of the heavily infested litter to the walls and ceiling. The problem also exists in high-rise caged-layer houses even though the larvae have greater distances to move to reach the insulation $(36,154)$.

Most of the climbing by the later-instar larvae and adults is at night. The larvae initiate the holes and tunnels in the insulation, and the adults follow. Although other factors may be involved, the major stimulus to larval climbing is the need for pupation sites when the litter is not adequate. With large populations of larvae this happens as the underlying soil sites for pupation becomes insufficient (57). The degree of climbing increases when the birds are removed from a house $(57,144)$. Adult flight occurs at night and is affected by the light: dark cycle $(57,58)$. When poultry manure containing beetles is spread on fields, the flying adults often move to nearby houses and businesses and create a serious annoyance problem to the inhabitants.

Methods to control $A$. diaperinus in poultry houses are only partially successful. Thorough cleaning of the houses and then leaving them empty and unheated for a prolonged period in a cold climate will reduce the rate of beetle 


\section{AXTELL \& ARENDS}

population increase in subsequent flocks, but these measures do not eradicate the infestation $(3,68)$. Application of insecticides to the structure (including the soil floor) after cleaning assists in lowering the beetle survival, but mixing insecticides with disinfectants, although a common practice, is risky due to a loss of both germicidal and insecticidal effectiveness (62). A variety of organophosphate, carbamate, and synthetic pyrethroid insecticides and borates are toxic to the beetles as residues on the structure or in the litter, but although effective in laboratory tests, they yield only temporary population reductions in the field $(3,164)$. Likewise, insect growth regulators (IGRs), juvenile hormone analogues, and avermectin have effects in laboratory tests but have not been demonstrated effective in the field $(49,108,167)$. In broiler and turkey growout houses insecticides are most effective when applied to the soil after cleanout and before adding new litter; this causes death of the late instar immatures when they move into the soil to pupate.

Biological control is an attractive concept, but few agents have been investigated. Steinernematid and heterorhabditid nematodes infect larvae, pupae, and adults of $A$. diaperinus in laboratory tests (61), but field tests with Steinernema feltiae gave only slight reductions in the rate of beetle population increases in broiler and turkey houses, apparently due to lack of persistence in the underlying soil under the relatively high temperatures $(56,59)$. Other strains and species of nematodes may be effective; Cycles and crashes of beetle populations in some houses which are otherwise inexplicable suggest the existence of pathogens that could be identified and exploited as biocontrol agents.

Monitoring beetle populations in poultry houses is necessary in order to carry out limited control measures, and the use of tube traps (corrugated cardboard inside a section of plastic pipe) is recommended, although their placement is critical $(142,154)$. A large number of traps and consistent placement of them are required owing to the aggregation behavior of the larvae and adults. Aggregation pheromones probably exist, but this has not been investigated. Secretions (benzoquinones) from abdominal glands have been identified (160) and are presumed to be defensive.

HIDE BEETLE Dermestes maculatus is generally less abundant than lesser mealworms in poultry houses, but on occasion it may be a serious pest, especially in high-rise (deep-pit) caged layer houses where Dermestes lardarius also has been reported as a pest $(31,86,154)$. In high-rise houses, $D$. maculatus populations can be monitored with tub traps placed on the surface of the accumulated manure (154). The behavior and economic significance of Dermestes are very similar to those of the lesser mealworm in that the beetles bore into the insulation and wood, presumably seeking pupation sites. The hide-beetle eggs are deposited in clusters in the manure or litter, and the 
larvae develop through a variable number of instars (5-7) requiring 20-30 days. The entire life cycle from egg to adult requires $30-40$ days $(32,158)$. Poultry manure by itself is not adequate for development, but spilled chicken feed provides suitable nutrients (32).

Effective control measures for $D$. macalatus in high-rise poultry houses are not known, though a variety of organophosphate, carbamate and synthetic pyrethroid insecticides and insect growth regulators are toxic to the adults and larvae in laboratory tests (31). No biological control agents are known. Pheromones may have a thus-far-unexplored potential in the control of hide beetles. Aggregation pheromones have been demonstrated in the feces of adult $D$. maculatus $(85,129,130)$, and evidence exists for a sex pheromone (147). Overall, the biology and control of Dermestes in poultry houses has been investigated very little compared to that of the more common litter beetle A. diaperinus.

\section{Filth Flies}

Worldwide the species of flies and other arthropods breeding in poultry manure are very similar, and their relationships to housing and poultry management schemes are basically the same. By far the greatest populations of flies occur in the caged-layer houses that are widely used for commercial egg production. In the narrow caged-layer houses manure is in close contact with the outside environment; this facilitates invasion and movement of the flies and their natural enemies. In wide-span houses with several walkways and rows of tiered cages, less contact occurs between the manure and the outside environment. In both the narrow and wide-span houses, the manure may accumulate, with removal only once or twice a year; opportunity then exists for a diverse, heterogeneous manure fauna to develop. Alternatively, a scraper or a flushing system may be used to remove the manure daily into a lagoon; in which case there is little or no fly breeding (unless a malfunction of the equipment results in an accumulation of manure). Disposal of the manure into lagoons creates a mosquito problem, however $(136,140)$. The wide-span houses may have open sides with adjustable curtains, or they may be enclosed with fans used for ventilation and temperature control (environmentally controlled houses). The high-rise or deep-pit caged layer houses are essentially the same type as the wide-span houses, except that the high-rise house is two-story with the birds on the top story; manure is allowed to accumulate on the first floor (on soil or concrete) for as long as 2 to 4 years. These houses may have curtain sides, or they be environmentally controlled. The condition of the manure and hence the heterogeneity of the fauna are greatly influenced by the amount of manure accumulation and the environmental conditions created in the "pit."

The second place fly breeding occurs prolificly is in the manure accumu- 


\section{AXTELL \& ARENDS}

lated under the slats in breeder houses. Since the feeders and waterers are positioned on the slatted portions in these houses, most of the manure and fly breeding occur there, and very little take place in the drier litter in the center of the houses. The manure under the slats accumulates for the life of the flock (12-18 months) and contact is limited between the manure and the external environment.

In the broiler and grow-out houses used to feed chickens and turkeys to market weight, little or no fly breeding occurs because the entire floor is covered with relatively dry litter. The litter is usually removed after 3-6 flocks and replaced with new wood shavings or other dry material. Some fly breeding may occur in wet litter around the waterers, but this is usually a minor problem.

Excessive numbers of filth flies (especially the house fly) in poultry facilities are unacceptable because the flies annoy workers, may disperse to nearby residences and businesses (engendering disputes and lawsuits), and often constitute a violation of local public health laws and regulations. Also, the flies by defecation and regurgitation cause spotting on the structure and equipment, on light fixtures (reducing illumination levels), and on eggs (presenting potential for transmission of pathogens into the freshly laid egg). Flies also provide a reservoir for a wide variety of pathogenic organisms affecting humans as well as poultry.

Because the fly problem is greatest in the types of caged-layer houses with accumulated manure under the cages and in breeder houses with accumulated manure under the slats, discussion of the ecology and management of flies applies to those production systems. Relevant reviews and surveys of manureinhabiting arthropods have been published $(9,14-17,20,80-82,94,127)$. The housing environment relevant to fly control has been described $(7,8$, 152).

FLy SPECIES The house fly, Musca domestica, is usually the most abundant and pestiferous fly species in poultry houses $(2,15,17)$, and it is the primary object of most fly management and control programs. The house-fly life cycle in poultry manure requires 6-10 days in warm housing. The eggs are deposited in batches in manure that has the most attractive odor and moisture level (53). Aided by their anterior sensory receptors (30), the larval stages move through the manure though usually not very deeply, owing to the anaerobic conditions. When there is no alternative, the larvae can tolerate rather liquid conditions. Pupations occurs in the drier portions near the surface and edges of the manure. Other muscoid flies $(2,150)$ common in poultry manure include Fannia canicularis, $F$. benjamini, and $F$. femoralis. In some locations $F$. canicularis and/or $F$. benjamini may be major pests for part of the year, but usually their populations decline quickly at high temperatures. 
Ophyra leucostoma, $O$. aenescens, and $O$. capensis, the so-called black garbage flies or dump flies, are sometimes abundant. They have basically the same life cycle and behavior as the house fly, except that the larvae of Ophyra prey on other arthropods as well as feed on the manure. Another muscid, Muscina stabulans, occasionally is abundant, and its larvae also prey to a limited extent on other fly larvae. The only larva of a blood-sucking muscid found in poultry manure is Stomoxys calcitrans.

The soldier fly, Hermetia illucens (Stratiomyidae), is common in poultry manure in some regions and may be especially abundant in high-rise houses. The robust larvae churn the manure and physically render the habitat less suitable for the house fly and other muscids $(18,148)$. Large numbers of soldier fly larvae in the manure also may inhibit oviposition by the house fly (26). The soldier fly oviposits (25) on the drier portions of the manure (up to a thousand eggs per mass). Larval development (5 instars) is slow (2 weeks or more), and the pupal stage lasts 2 weeks or more. A complete life cycle from egg to adult in poultry houses requires $40-60$ days and consequently larvae can become very abundant. The adults are slow flying, and although they may be found resting on vegetation around the house where they feed on plant pollen, they do not readily disperse in sufficient numbers to cause problems in nearby residences or businesses. Although the soldier fly larvae provide the benefit of discouraging house fly and Fannia development, the larvae cause the manure to become so liquified that it is difficult to remove and may flow onto walkways or undermine foundations of the poultry house. In breeder houses, the liquified manure may flow from beneath the slats and adhere to the feet of the hens; this results in manure adhering to the surface of the eggs as they are laid in the nest boxes and, consequently, a risk of pathogens entering the egg through the moist shell at time of laying. Such pathogens can cause decreased hatch and chick growth.

The Ophyra flies breeding in poultry houses have a slighly longer life cycle than that of house flies, but the larvae occupy the same microhabitats in the manure (87). Ophyra larvae prey on house fly larvae and often become the dominant fly species. An Ophyra aenescens larva may destroy 20 house fly larvae per day (63). The use of Ophyra aenescens as a biocontrol agent against the house fly has been suggested (117), and its limited dispersal from poultry houses has been reported (118). However, in the mid-1970s $O$. aenescens was accidentally introduced from the New World into Europe, where it is rapidly becoming a new pest, along with $O$. capensis and $O$. leucostoma, in poultry production facilities as well as in refuse dumps (1; $115,116,150,155)$. In Africa, $O$. capensis is the most common Ophyra in poultry facilities $(80,81,121)$. Ophyra flies appear to leave fecal and regurgitation spots on the structure, light fixtures, equipment, and eggs in a manner similar to that of house flies. 


\section{AXTELL \& ARENDS}

FLY PREDATORS, PARASITES, AND PATHOGENS Although the diverse fauna in accumulated poultry manure includes a variety of minor predators, worldwide the major, most abundant predators on the eggs and first-instar larvae of the house fly (and other muscids) are the mite Macrocheles muscaedomesticae (Macrochelidae) and the beetle Carcinops pumilio (Histeridae). In some regions Carcinops troglodytes may replace $C$. pumilio (82). Other common mite predators are Fuscuropoda vegetans (Uropodidae) and Poecilochirus spp. (Parasitidae). These major predators and Ophyra larvae may destroy up to 40 house fly immatures per predator per day $(58,63,64$, 170, 172).

The mite and beetle predators of the house fly immatures are most effective in manure that is properly managed so that it is not too wet and accumulates in a distinct pile ("cone formation"). The distribution of C. pumilio, M. muscaedomesticae, and $F$. vegetans in accumulated poultry manure has been well documented $(23,65,66,151,170)$; those predators are most abundant at and near the crest and slightly beneath the surface, in the areas most likely to have house fly eggs and first-instar larvae.

The parasitids are more active than the other mites and rapidly run around on the surface of the manure mostly near the crest. These predators feed on nematodes and other small arthropods as well as immatures of the house fly and other Diptera. Larvae of Sphaeroceridae (Diptera) are common food for Carcinops (67). The mites exhibit a succession as manure accumulates and ages, with the Poecilochirus invading early, followed by Macrocheles, and subsequently Fuscuropoda. The mites exhibit phoresy $(52,83)$, with the house fly the most common carrier, which is regulated by olfactory responses to the flies and the aging manure; this is a mechanism for dispersal to the most favorable fly breeding areas.

Hymenopterous parasites (Ptermolalidae) are a major factor in destroying fly pupae in poultry facilities (as well as in other confined livestock operations). The extensive literature on this topic is summarized by Axtell (17), Patterson \& Rutz (124), and Rueda \& Axtell (135). Naturally occurring parasite populations are often substantial and apparently contribute significantly to fly control $(104,107,113,134,138,141)$ although it is difficult to quantify the impact $(124,126)$. Augmentative releases of Spalangia and Muscidifurax have successfully reduced the abundance of house flies in poultry facilities $(93,110,122,124,137,139,149)$. Naturally occurring parasite populations may be large, and these are enhanced by dry manure, which provides areas where the house fly pupae are readily accessible to the parasites. Although parasites are important limiting factors to fly populations and are even offered for sale as biocontrol agents, many questions remain unresolved concerning the most effective species or combination of species, how to evaluate the degree of parasitism, how to time augmentative releases, 
and how to integrate parasites into a total fly management program (124, 126). These questions are presently resolved empirically while awaiting the results of further research and population modelling $(17,20,168)$.

Little attention has been given to fly pathogens in poultry production facilities except for fungi and evaluation of nematodes as possible biocontrol agents. The fungus Entomophthora muscae is a common pathogen of the house fly and other filth flies; perhaps ways can be found to exploit it (91, 114 ), but it has been investigated in only a few locations. Several steinernematid and heterorhabditid nematodes are infective to house-fly larvae in the laboratory but rapidly die when in poultry manure. Hence they have little value as filth fly control agents in poultry houses $(60,69,111,112,132)$.

FLY MANAGEMENT Control of the house fly and other filth flies in poultry houses requires a management approach using cultural, biological, and chemical techniques, with appropriate monitoring of the fly populations (14-16). Although details will vary with the type of housing, the manure handling system, and climatic situation, the principles of fly mangement are universal.

Cultural methods are primary and basically involve keeping the manure as dry as possible. This is accomplished by proper building design and ventilation to maximize air flow over the manure, by provision for drainage of water away from the house, and by careful maintenance of the bird watering system to minimize leaks. To conserve part of the heterogeneous manure fauna, especially fly predators and parasites, the manure should not be totally removed in one brief span of time (125). Whenever possible, portions of the manure should be removed in a staggered schedule, preferably during the cooler months when there is low fly activity; a base of old manure should be left to provide absorbancy for the fresh manure as well as harborage for beneficial arthropods. These cultural manure management practices are the basis for biological control, which consists of encouraging a heterogeneous population of predators and parasites that occur naturally and suppress the fly population. Augmentation by parasite releases is a future avenue for biological control, but quantitative guidelines for augmentation are presently lacking.

Chemical methods of fly control are proven supplements to cultural and biological methods. Unfortunately most insecticides effective against house flies and other filth flies are also toxic to predators and parasites. Consequently, routine larviciding of the poultry manure is incompatible with maintainence of the beneficial arthropods. Spot treatment of small areas containing unusually high numbers of fly larvae is acceptable. Using cyromazine as a feed additive or in direct application to the manure is acceptable because that chemical is relatively nontoxic to predacious mites and beetles (19). Some selectivity of chemicals can be achieved by the choice of applica- 


\section{AXTELL \& ARENDS}

tion method. The use of fly baits and selective application of fly control chemicals to the interior upper portions of the poultry house where flies rest are compatible with biological control agents. Aerosol and mist applications for temporary adult fly control are sometimes needed in crisis situations, and if their use is limited, these should have little effect on the populations of predators and parasites (146). House flies develop resistance to insecticides very rapidly, and few effective chemicals for control are available. Even with the newer synthetic pyrethroids and cyromazine, some indications of fly resistance have been reported (24). Consequently, chemical control of flies should be only a supplement to cultural and biological control methods.

A major problem in managing fly populations is monitoring to evaluate the potential for reinvasion as well as fly dispersal. Practical monitoring methods focus on the adult fly; a variety of techniques have been used, including resting counts, grid counts, sticky ribbons, baited jug traps, and spot cards $(21,28,153)$. The baited jug traps and spot cards are the most thoroughly researched and are related to actual fly numbers; the cards provide a simple, practical method for use in the poultry industry (98-101). Inconsistencies of results using the various monitoring methods in different situations have been reported, and each method has its advantages and disadvantages. Uniform, consistent application of a method at frequent intervals during a fly season will provide a measure of changes in fly abundance that is superior to erratic subjective impressions and will establish a basis for decision-making in regard to fly control measures. Also, a body of quantitative monitoring data by a proven method is required in case of lawsuits of other actions under public health laws.

\section{SUMMARY}

The worldwide spread of modern, high-density confined poultry production systems under the direction of integrators has intensified the importance of a select number of arthropod ectoparasites and habitat pests. This concentrated production of poultry provides artificial ecosystems that are sometimes ideal for the development of large populations of arthropod pests. At the same time the systems are amenable to integrated pest management involving a multipest and multimethod approach to reducing or eliminating arthropod pests. Since rodents are major pests, they should be included in an integrated pest management program to make the program most cost-effective and attractive to the integrators and producers (5).

Quantitative data are scarce on economic effects, and the concept of economic thresholds is difficult to apply either to ectoparasites or to habitat pests. The risk of transporting ectoparasites among flocks is difficult to evaluate and necessitates treatment after early detection of the arthropods. 
Flies and litter beetles present a threat of disease transmission and the potential for lawsuits from neighbors or public health agencies that are factors not subject to easy cost estimates. The monetary losses of a flock devastated by disease or a farm forced to close are so great that the risks are unacceptable. Production losses from lowered feed conversion ratios and insulation damage are likely to be detected by the sophisticated record-keeping of the integrators. Minimal use of pesticides and other chemicals on poultry and in poultry housing is an objective of the integrators and, consequently, an integrated pest management (IPM) approach that reduces the need for pesticides is attractive.

The key to further development of effective arthropod management programs for poultry is the implementation of pest and disease monitoring programs for the complete system. Improvements in arthropod sampling methods and more attention to monitoring the biosecurity systems to minimize ectoparasite dispersal are needed. The integrators have servicemen who regularly visit the production facilities and can be trained to perform monitoring functions and to instigate and supervise integrated pest management measures. With the increasing use of computers by the integrators, the prospects for utilizing the monitoring data in predictive computer simulation models for pest management decision-making justify more efforts to develop such tools $(64,102,168)$. Future poultry pest managment programs must be based on sound data, which presently is too limited, and must be flexible enough to adjust rapidly to evolving pest problems in rapidly changing production systems.

\section{Literature Cited}

1. Adams, R. G. 1984. Ophyra species as predators in animal houses, with a key to species occurring in Europe (Diptera: Muscidae). Entomol. Gaz. 35:24346

2. Anderson, J. R., Poorbaugh, J, H. 1964. Observations on the ethology and ecology of various Diptera associated with northern California poultry ranches. J. Med. Entomol. 1:131-47

3. Arends, J. J. 1987. Control, management of the litter beetle. Poult. Dig. (April):172,174-176

4. Arends, J. J. 1989. External parasites and poultry pests. In Diseases of Poultry, ed. B. W. Calnek, H. J. Barnes, C. W. Beard, et al, Iowa: Iowa Univ. Press. 9th ed. In press

5. Arends, J. J., Robertson, S. H. 1986. Integrated pest management for poultry production: Implementation through integrated poultry companies. Poult. Sci, 65:675-82
6. Arends, J. J., Robertson, S. H., Payne, C. S. 1984. Impact of northern fowl mite on broiler breeder flocks in North Carolina. Poult. Sci. 63:1457-61

7. Armitage, D. M. 1985. Environment of deep-pit poultry houses: Survey of air and manure temperatures in British houses. Br. Poult. Sci. 26:275-80

8. Armitage, D. M. 1985. Environment of deep-pit poultry houses: Changes in manure moisture with air movement. $\mathrm{Br}$. Poult. Sci. 26:281-85

9. Armitage, D. M. 1986 . Population changes of four species of insects (Col. \& Dipt.) in three deep pit poultry houses. Entomol. Mon. Mag. 122:7577

10. Arthur, F. H., Axtell, R. C. 1982. Comparisons of permethrin formulations and application methods for northern fowl mite control on caged laying hens. Poult. Sci. 61:879-84

11. Arthur, F. H., Axtell, R. C. 1983. 
Northern fowl mite population development on laying hens caged at three colony sizes. Poult. Sci. 62:424-27

12. Arthur, F. H., Axtell, R. C. 1983. Susceptibility of northern fowl mites in North Carolina to five acaricides. Poult. Sci. 62:428-32

13. Axtell, R. C. 1981. Livestock integrated pest management (IPM): Principles and prospects, In Systems Approach to Animal Health and Production, ed. F. W. Knapp, pp. 31-40. Lexington: Univ. Kentucky

14. Axtell, R. C. 1985. See Ref. 169, pp. 269-95

15. Axtell, R. C. 1986. Fly Control in Confined Livestock and Poultry Production. Tech. Monogr. Greensboro, NC: CibaGeigy Corp.

16. Axtell, R. C. 1986. Entomol. Soc. Am. Misc. Publ. 61:1-9

17. Axtell, R. C. 1986 . Fly management in poultry production: Cultural, biological, and chemical. Poult. Sci. 65:657-67

18. Axtell, R. C., Edwards, T. D. 1970. Hermetia illucens control in poultry manure by larviciding. J. Econ. Entomol. 63:1786-87

19. Axtell, R. C., Edwards, T. D. 1983. Efficacy and non-target effects of Larvadex as a feed additive for controlling house flies in caged-layer poultry manure. Poult. Sci. 62:2371-77

20. Axtell, R. C., Rutz, D. A. 1986. Entomol. Soc. Am. Misc. Publ. 61:88-100

21. Beck, A. F., Turner, E. C. Jr. 1985. A comparison of five house-fly (Diptera: Muscidae) population monitoring techniques. J. Med. Entomol. 22:346-48

22. Bergmann, V., Valentin, A., Scheer, J. 1986. Hautkarzinomatose bei Broilern. Monat. Veterinaermed. 41:815-17

23. Bills, G. T. 1973. Biological fly control in deep-pit poultry houses. Br. Poult. Sci. 14:209-12

24. Bloomcamp, C. L., Patterson, R. S., Koehler, P. G. 1987. Cyromazine resistance in the house fly (Diptera: Muscidae). J. Econ. Entomol. 80:352-57

25. Booth, D. C., Sheppard, C. 1984. Oviposition of the black soldier fly, Hermetia illucens (Diptera: Stratiomyidae): Eggs, masses, timing, and site characteristica. Environ. Entomol. 13:421-23

26. Bradley, S. W., Sheppard, D. C. 1984. House fly oviposition inhibition by larvae of Hermetia illucens, the black soldier fly. J. Chem. Ecol. 10:853-59

27. Brown, K. I., Nestor, K. E. 1973. Some physiological responses of turkeys selected for high and low adrenal response to cold stress. Poult. Sci. $52: 1948-54$
28. Burg, J. G., Axtell, R. C. 1984. Monitoring house fly, Musca domestica (Diptera: Muscidae), populations in caged-layer poultry houses using a baited jug-trap. Environ. Entomol. 13:1083-90

29. Burg, J. G., Collison, C. H., Mastro, A. M. 1988. Comparative analysis of precipitating antibodies in White Rock and Fayoumi hens injected with bovine serum albumin or crude mite extract with resulting effects on northern fowl mite, Ornithonyssus sylviarum (Acari: Macronyssidae) population densities. Poult. Sci. 67:1015-19

30. Chu, I-Wu, Axtell, R. C. 1971. Fine structure of the dorsal organ of the house fly larva (Musca domestica L.). Z. Zellforsch. Mikrosk. Anat. 117:17-34

31. Cloud, J. A., Collison, C. H. 1985. Laboratory evaluation of insecticides for control of adult and larval hide beetles, Dermestes maculatus DeGeer, from poultry houses. J. Agric. Entomol. 2:297-308

32. Cloud, J. A., Collison, C. H. 1986. Comparison of various poultry house litter components for hide beetle (Dermestes maculatus DeGeer) larval development in the laboratory. Poult. Sci. 65:1911-14

33. Craig, J. V., Craig, J. A., Vargas, J. V. 1986. Corticosteroids and other indicators of hen's well-being in four laying house environments. Poult. Sci. 65:856-63

34. Crystal, M. M. 1986. Artificial feeding of northern fowl mites, Ornithonyssus sylviarum (Canestrini and Fanzago) (Acari: Macronyssidae), through membranes. J. Parasitol. 72:550-54

35. Crystal, M. M. 1987. Factors affecting the feeding of northern fowl mites, Ornithonyssus sylviarum, through a membrane. Entomol. Exp. Appl. 45:205-9

36. Despins, J. L., Turner, E. C. Jr., Ruszler, P. L. 1987. Construction profiles of high rise caged layer houses in association with insulation damage caused by the lesser mealworm, Alphitobius diaperinus (Panzer) in Virginia. Poult. Sci. 66:243-50

37. DeVaney, J. A. 1976. Effects of the chicken body louse, Menacanthus stramineus, on caged layers. Poult. Sci. $55: 430-35$

38. DeVaney, J. A. 1978. A survey of poultry ectoparasite problems and their research in the United States. Poult. Sci. 57:1217-20

39. DeVaney, J. A. 1979. The effects of the northern fowl mite, Ornithonyssus syl- 
viarum, on egg production and body weight of caged White Leghorn hens. Poult. Sci. 58:191-94

40. DeVaney, J. A. 1986. Ectoparasites. Poult. Sci. 65:649-56

41. DeVaney, J. A., Augustine, P. C. 1988. Correlation of estimated and actual northern fowl mite populations with the evolution of specific antibody to a low molecular weight polypeptide in the sera of infested hens. Poult. Sci. 67:54956

42. DeVaney, J. A., Beerwinkle, K. R. 1980. A nonchemical method of controlling the northern fowl mites, Ornithonyssus sylviarum (Canestrini and Fanzago), on caged White Leghorn hens. Poult. Sci. 59:1226-28

43. DeVaney, J. A., Beerwinkle, K. R. 1980. Effects of microwave and various combinations of ambient temperature and humidity exposures on off-host survival of northern fowl mites. Poult. Sci. 59:2198-2201

44. DeVaney, J. A., Beerwinkle, K. R. 1983. Control of the northern fowl mites on innate objects by fumigation: field studies. Poult. Sci. 62:43-46

45. DeVaney, J. A., Beerwinkle, K. R., Ivie, G. W. 1982. Residual activity of selected pesticides on laying hens treated for northern fowl mite control by dipping. Poult. Sci. 61:1630-36

46. DeVaney, J. A., Quisenberry, J. H., Doran, B. H., Bradley, J. W. 1980. Dispersal of the northern fowl mite, Ornithonyssus sylviarum (Canestrini and Fanzago) and the chicken body louse, Menacanthus stramineus (Nitzch) among thirty strains of egg-type hens in a caged laying house. Poult. Sci. 59:1745-49

47. Drummond, R. O., George, J. E., Kunz, S. E. 1988. Control of Arthropod Pests of Livestock: A Review of Technology. Baton Rouge, Fla: CRC Press

48. Edgar, S. A., King, D. F. 1950. Effect of the body louse, Eomenacanthus stramineus, on mature chickens. Poult. Sci. 29:214-19

49. Edwards, J. P., Abraham, L. 1985. Laboratory evaluation of two insect juvenile hormone analogues against Alphitobius diaperinus (Panzer) (Coleoptera: Tenebrionidae). J. Stored Prod. Res. 21:18994

50. Eley, S. M., Gardner, R., Molyneux, D. H., Moore, N. F. 1987. A reovirus from the bedbug, Cimex lectularius. $J$. Gen. Virol. 68:195-99

51. Elowni, E. E., Elbihari, S. 1979. Natural and experimental infection of the beetle, Alphitobius diaperinus (Cole- optera: Tenebrionidae) with Choanotaenia infundibulum and other chicken tapeworms. Vet. Sci. Commun. 3:17173

52. Farish, D. J., Axtell, R. C. 1971. Phoresy redefined and examined in $\mathrm{Mac}$ rocheles muscaedomesticae (Acarina: Macrochelidae). Acarologia 13:16-29

53. Fatchurochim, S., Geden, C. J., Axtell, R. C. 1989. Filth fly (Diptera) oviposition and larval development in poultry manure of various moisture levels. $J$. Entomol. Sci. 24:224-31

54. Fletcher, M. G., Lancaster, J. L. Jr. 1984. In vitro rearing of the northern fowl mite (Acari: Macronyssidae). $J$. Econ. Entomol. 77:1504-6

55. Freeman, B. M. 1976. Stress and the domestic fowl: a physiological reappraisal. World's Poult. Sci. J. 32:24956

56. Geden, C. J., Arends, J. J., Axtell, R. C. 1987. Field trials of Steinernema feltiae (Nematoda: Steinernematidae) for control of Alphitobius diaperinus (Coleoptera: Tenebrionidae) in commercial broiler and turkey houses. J. Econ. Entomol. 80:135-41

57. Geden, C. J., Axtell, R. C. 1987. Factors affecting climbing and tunneling behavior of the lesser mealworm (Coleoptera: Tenebrionidae). J. Econ. Entomol. 80:1197-204

58. Geden, C. J., Axtell, R. C. 1988. Predation by Carcinops pumilio (Coleoptera: Histeridae) and Macrocheles muscaedomesticae (Acarina Macrochelidae) on the house fly (Diptera: Muscidae): Functional response, effects of temperature, and availability of alternative prey. Environ. Entomol. 17:739-44

59. Geden, C. J., Axtell, R. C. 1988. Effect of temperature on nematode (Steinernema feltiae [Nematoda: Steinernematidae]) treatment of soil for control of lesser mealworm (Coleoptera: Tenebrionidae) in turkey houses. J. Econ. Entomol. 81:800-3

60. Geden, C. J., Axtell, R. C., Brooks, W. M. 1986. Susceptibility of the house fly, Musca domestica (Diptera: Muscidae), to the entomogenous nematodes Steinernema feltiae, S. glaseri (Steinernematidae) and Heterorhabditis heliothidis (Heterorhabditidae). J. Med. Entomol. 23:326-32

61. Geden, C. J., Axtell, R. C., Brooks, W. M. 1985. Susceptibility of the lesser mealworm Alphitobius diaperinus (Coleoptera: Tenebrionidae) to the entomogenous nematodes Steinernema feltiae, $S$. glaseri (Steinernematidae) and Heterorhabditis heliothidis (Heter- 
orhabditidae). J. Entomol. Sci. 20:33139

62. Geden, C. J., Edwards, T. D., Arends, J. J., Axtell, R. C. 1987. Efficacies of mixtures of disinfectants and insecticides. Poult. Sci. 66:659-65

63. Geden, C. J., Stinner, R. E., Axtell, R. C. 1988. Predation by predators of the house fly in poultry manure: Effects of predator density, feeding history, interspecific interference, and field conditions. Environ. Entomol. 17:320-29

64. Geden, C. J., Stinner, R. E., Kramer, D. A., Axtell, R. C. 1989. MACMOD: A simulation model for Macrocheles muscaedomesticae (Acarina: Macrochelidac) population dynamics and rates of predation on immature house fly (Diptera: Muscidae). Environ. Entomol. 18: In press

65. Geden, C. J., Stoffolano, J. G. Jr. 1987. Succession of manure arthropods at a poultry farm in Massachusetts, USA, with observations on Carcinops pumilio (Coleoptera: Histeridae) sex ratios, ovarian condition, and body size. J. Med. Entomol. 24:212-20

66. Geden, C. J., Stoffolano, J. G. Jr. 1988. Dispersion patterns of arthropods associated with poultry manure in enclosed houses in Massachusetts: Spatial distribution and effects of manure moisture and accumulation time. J. Entomol. Sci. 23:136-48

67. Geden, C. J., Stoffolano, J. G. Jr., Elkinton, J. S. 1987. Prey-mediated dispersal behavior of Carcinops pumilio (Coleoptera: Histeridae). Environ. Entomol. 16:415-19

68. Geissler, V. H., Kosters, J. 1972. Die hygienische Bedeutung des Getreideschimmerlkafers (Alphitobius diaperinus Panz.) in der Geflugelmast. Dtsch. Tierarztl. 79:177-204

69. Georgis, R., Mullens, B. A., Meyer, J. A. 1987. Survival and movement of insect parasitic nematodes in poultry manure and their infectivity against Musca domestica. J. Nematol. 19:292-95

70. Glees, E. E., Raun, E. S. 1959. Effects of chicken body louse infestation on egg production. J. Econ. Entomol. 52:35859

71. Gogoi, A. R., Chaudhuri, R. P. 1982. Contribution to the biology of fowl cestodes Raillietina tetragona, Raillietina echinobothrida and Raillietina cesticillus. Indian J. Anim. Sci. 52:246-53

72. Gross, W. B., Colmano, G. 1969. The effect of social isolation on resistance to some infectious diseases. Poult. Sci. 48:514-20

73. Gross, W. B., Colmano, G. 1971.
Effect of infectious agents on chickens selected for plasma corticosterone response to social stress. Poult. Sci. 49:1213-17

74. Hall, R. D., Gross, W. B., Turner, E. C. Jr. 1978. Preliminary observations on northem fowl mite infestations on estrogenized roosters and in relation to initial egg production in hens. Poult. Sci. 57:1088-90

75. Hall, R. D., Turner, E. C. Jr., Gross, W. B. 1978. Effect of cage densities on northern fowl mite populations in commercial cage-layer operations. Poult. Sci. 57:564-66

76. Hall, R. D., Vandepopuliere, J. M., Fischer, F. J., Lyons, J. J., Doisy, K. E. 1983. Comparative efficacy of plastic strips with permethrin and permethrin dust for northern mite control on caged laying hens. Poult. Sci. 62:612-15

77. Hall, R. D., Vandepopuliere, J. M., Fischer, F. J., Lyons, J. J., Vanhorn, J. D. 1984. A new in-cage treatment system for control of northern fowl mitcs on laying hens. Poult. Sci. 63:62832

78. Hofmann, K., Grose, W. 1987. Untersuchungen zur circadianen lokomotorischen Aktivität von Alphitobius diaperinus (Panz. 1797). Wiss. Z. Univ. Halle 36:84-91

79. Hofstad, M. S., Calnek, B. W., Helmbolt, C. F., Reid, W. M., Yoder, H. W. Jr., eds. 1972. Diseases of Poultry. Ames: Iowa State Univ. Press. 7th ed.

80. Hulley, P. E. 1983. A survey of the flies breeding in poultry manure, and their potential natural enemies. J. Entomol. Soc. S. Afr. 46:37-47

81. Hulley, P. E. 1986. Factors affecting numbers of Musca domestica Linnaeus (Diptera: Muscidae) and some other flies breeding in poultry manure. J. Entomol. Soc. S. Afr. 49:19-27

82. Hulley, P. E., Pfleiderer, M. 1988. The Coleoptera in poultry manure-potential predators of house flies, Musca domestica Linnaeus (Diptera: Muscidae). J. Entomol. Soc. S. Afr. 51:17-29

83. Hunter, P. E., Rosario, R. M. 1988. Associations of mesostigmata with other arthropods. Annu. Rev. Entomol. $33: 393-417$

84. Ichinose, T., Shibazaki, S., Ohta, R. 1980. Studies on the biology and mode of infestation on the tenebrionid beetle, Alphitobius diaperinus Panzer, harmful to broiler-chicken houses. Jpn. J. Appl. Entomol. Zool. 24:167-74

85. Jaskulska, B., Rakowski, G., Cymborowski, B. 1987. The effect of juvenile hormone on aggregative behaviour of 
Dermestes maculatus. Comp. Biochem. Physiol. A87:771-73

86. Jefferies, M. G. 1980. The occurrence of Dermestes species (Coleoptera: Dermestidae) in "deep pit" poultry houses in Britain. Entomol. Gaz. 30:207-12

87. Johnson, W. T., Venard, C. E. 1957. Observation on the biology and morphology of Ophyra aenescens (Diptera: Muscidae). Ohio J. Sci. 57:21-26

88. Jones, E. M., Kissam, J. B. 1983. The effectiveness of polyvinyl chloride plastic bands impregnated with permethrin as a control for the northern fowl mite, Ornithonyssus sylviarum (Canestrini and Fanzago), infested caged laying hens. Poult. Sci. 62:113-16

89. Kirkwood, A. 1963. Longevity of the mites, Dermanyssus gallinae and Liponyssus sylviarum. Exp. Parasitol. 14:358-66

90. Kirkwood, A. C. 1967. Anemia in poultry infected with the red mite Dermanyssus gallinae. Vet. Rec. 80:514

91. Kramer, J. P., Steinkraus, D. C. 1987. Experimental introduction of the mycosis caused by Entomophthora muscae in a population of house flies (Musca domestica) in a poultry building. $J . N Y$ Entomol. Soc. 95:114-17

92. Kulash, W. M. 1947. DDT for control of bedbugs in poultry houses. Poult. Sci. 26:44-47

93. Legner, E. F., Dietrick, E. I. 1974. Effectiveness of supervised control practices in lowering population densities of synanthropic flies on poultry ranches. Entomophaga 19:467-78

94. Legner, E. F., Olton, G. S. 1970. Worldwide survey and comparison of adult predator and scavenger insect pop. ulations associated with domestic animal manure where livestock is artificially congregated. Hilgardia 40:225-66

95. Lemke, L. A., Collison, C. H., Kim, K. C. 1988. Host digestion to determine populations of the northern fowl mite, Ornithonyssus sylviarum (Acari: Macronyssidae), on mature chickens. $J$. Med. Entomol. 25:183-85

96. Lemke, L. A., Kissam, J. B. 1986. The status of northern fowl mite research: how far have we come? J. Agric. Entomol. 3:255-64

96a. Le Torc'h, J. M., Letenneur, R. 1983. Essais en laboratoire de resistance de differents isolants thermiques aux perforations du tenebrion, Alphitobius diaperinus Panzer, (col. Tenebrionidae). C. R. Sci. Acad. Agric. France 6:188200

97. Loomis, E. C., Bramhall, E. L., Allen, J. A., Ernst, R. A., Dunning, L. L.
1970. Effects of the northern fowl mite on White Leghorn chickens. J. Econ. Entomol. 63:1885-89

98. Lysyk, T. J., Axtell, R. C. 1985. Comparison of baited jug-trap and spot cards for sampling house fly, Musca domestica (Diptera: Muscidae), populations in poultry houses. Environ. Entomol. $14: 815-19$

99. Lysyk, T. J., Axtell, R. C. 1986. Estimating numbers and survival of house flies (Diptera: Muscidae) with mark/ recapture methods. J. Econ. Entomol. 79:1016-22

100. Lysyk, T. J., Axtell, R. C. 1986. Field evaluation of three methods for monitor. ing populations of house flies (Musca domestica) (Diptera: Muscidae) and other filth flies in three types of poultry housing systems. J. Econ. Entomol. 79:144-51

101. Lysyk, T. J., Axtell, R. C. 1986. Movement and distribution of house flies (Diptera: Muscidae) between habitats in two livestock farms. I. Econ. Entomol. 79:993-98

102. Lysyk, T. J., Axtell, R. C. 1987. A simulation model of house fly (Diptera: Muscidae) development in poultry manure. Can. Entomol. 119:427-37

103. MacCreary, D., Catts, E. P. 1954. Ectoparasites of Delaware poultry including a study of litter fauna. Del. Agric. Exp. Sin. Bull. 307:1-22

104. Mandeville, J. D., Mullens, B. A., Meyer, J. A. 1988. Rearing and host suitability of Fannia canicularis (L.) for parasitization by Muscidifurax zaraptor Kogan and Legner (Hymenoptera: Pteromalidae). Can. Entomol. 120:153-59

105. Manuel, M. F. 1981. The ectoparasites (lice and mites) occurring on domestic chickens in the Phillippines. Philippine J. Vet. Med. 20:87-100

106. Matthysse, J. G., Jones, C. J., Purnasiri, A. 1974. Development of northern fowl mite population on chickens, effects on the host and immunology. Search Agric. 4:1-39

107. Merchant, M. E., Flanders, R. V., Williams, R. E. 1987. Seasonal abundance and parasitism of house fly (Diptera: Muscidae) pupae in enclosed, shallowpit poultry houses in Indiana. Environ. Entomol. 16:716-21

108. Miller, R. W., Redfern, R. E. 1988 Feed additives for control of lesser mealworm (Coleoptera: Tenebrionidae) in poultry broiler houses. J. Econ. Entomol. 81:1137-39

109. Misirlioglu, H. S. 1987. Economics of feed conversion. Broiler Industry (Sept.):76-81 
110. Morgan, P. B., Weidhaas, D. E., Patterson, R. S. 1981. Host-parasite relationship: Programmed releases of Spalangia endius Walker and Muscidifurax raptor Girault and Sanders against estimated populations of Musca domestica. J. Med. Entomol. 18:158-66

111. Mullens, B. A., Meyer, J. A., Cyr, T. L. 1987. Infectivity of insect-parasitic nematodes (Rhabditida: Steinemematidae, Heterorhabditidae) manure-breeding flies (Diptera: Muscidae). Environ. Entomol. 16:769-73

112. Mullens, B. A., Meyer, J. A., Georgis, R. 1987. Field tests of insect-parasitic nematodes (Rhabditida: Steinernematidae, Heterorhabditidae) against larvae of manure-breeding flies (Diptera: Muscidae) on caged-layer poultry facilities. $J$. Econ. Entomol. 80:438-42

113. Mullens, B. A., Meyer, J. A., Mandeville, J. D. 1986. Seasonal and diel activity of filth fly parasites (Hymenoptera: Pteromalidae) in caged-layer poultry manure in southern California. Environ. Entomol. 15:56-60

114. Mullens, B. A., Rodriguez, J. L., Meyer, J. A. 1987. An epizootiological study of Entomopthora muscae in muscoid fly populations on southem California poultry facilities, with emphasis on Musca domestica. Hilgardia 55(3):1-41

115. Müller, P. 1982. Zur Bedeutung des Musca domestica-Antagonisten Ophyra aenescens (Diptera: Muscidae) III. Laborversuche zur Wechselwirkung zwischen den Larven von $M$. domestica und $O$. aenescens. Angew. Parasitol. 23:143-54

116. Müller, P., Schumann, H., Betke, P., Schultka, H., Ribbeck, R., Hiepe, T. 1981. Zur Bedeutung der Musca domestica-Antagonisten Ophyra aenescens (Diptera:Muscidae). I. Zum Auftreten von Ophyra aenescens in Anlagen der Tierproduktion. Angew. Parasitol. 22: 212-16

117. Nolan, M. P. III, Kissam, J. B. 1985. Ophyra aenescens: A potential biocontrol alternative for house fly control in poultry houses. J. Agric. Entomol. 2:192-95

118. Nolan, M. P. III, Kissam, J. B. 1987. Nuisance potential of a dump fly, $O p$ hyra aenescens (Diptera: Muscidae), breeding at poultry farms. Environ. Entomol. 16:828-31

119. North, M. O. 1984. Commercial Chicken Production Manual. Westport, Conn: AVI Publ. 3rd ed.

120. O'Connor, J. P. 1987. Alphitobius diaperinus (Panzer) (Col. Tenebrionidae) damaging polystyrene insulation in an
Irish piggery. Entomol. Mon. Mag. 123:50

121. Olckers, T., Hulley, P. E. 1984. Facultative predation of house fly larvae by larvae of Ophyra capensis (Wiedemann) (Diptera: Muscidae). J. Entomol. Soc. S. Afr. 47:231-37

122. Olton, G. S., Legner, E. F. 1975. Winter inoculative releases of parasitoids to reduce house flies in poultry manure. $J$. Econ. Entomol. 68:35-38

123. Parkhurst, R. C., Mountney, G. J. 1988. Poultry Meat and Egg Production. New York: Van Nostrand Reinhold

124. Patterson, R. S., Rutz, D. A., eds. 1986. Biological control of muscoid flies. Entomol. Soc. Am. Misc. Publ. 61:1-174

125. Peck, J. H., Anderson, J. R. 1970. Influence of poultry-manure removal schedule on various Diptera larvae and selected arthropod predators. J. Econ. Entomol. 63:82-90

126. Peterson, J. J., Meyer, J. A. 1985. Evaluation of methods presently used for measuring parasitism of stable flies and house flies (Muscidae: Diptera) by pteromalid wasps (Pteromalidae: Hymenoptera: J. Kans. Entomol. Soc. 58:84-90

127. Pfeiffer, D. G., Axtell, R. C. 1980 . Coleoptera of poultry manure in cagedlayer houses in North Carolina. Environ. Entomol. 9:21-28

128. Preiss, F. J., Davidson, J. A. 1971. Adult longevity, preoviposition period and fecundity of Alphitobius diaperinus in the laboratory (Coleoptera: Tenebrionidae). J. Ga. Entomol. Soc. 6:105-9

129. Rakowski, G., Cymborowski, B, 1982. Aggregation pheromone in Dermestes maculatus: effects on larval growth and developmental thythms. Int. J. Invertebr. Reprod. 4:249-54

130. Rakowski, G., Cymborowski, B. 1986. Some environmental and physiological factors influencing the response of the hide beetle, Dermestes maculatus, to aggregation pheromone. Int. J. Invertebr. Reprod. Dev. 9:35-41

131. Randall, K. 1985. Food protein: Third world production trends indicate a meat deficit but enough eggs by 2000 . World Poult. (Sept):30

132. Renn, N., Barson, G., Richardson, P. N. 1985. Preliminary laboratory tests with two species of entomophilic nematodes for control of Musca domestica in intensive animal units. Ann. Appl. Biol. 106:229-33

133. Reyna, P. S., McDougald, L. R., Mathis, G. F. 1983. Survival of coccidia in poultry litter and reservoirs of infection. Avian Dis. 27:464-73 
134. Rueda, L. M., Axtell, R. C. 1985. Comparison of hymenopterous parasites of house fly, Musca domestica (Diptera: Muscidae), pupae in different livestock and poultry production systems. Environ. Entomol. 14:217-22

135. Rueda, L. M., Axtell, R. C. 1985. Guide to common species of pupal parasites (Hymenoptera: Pteromalidae) of the house fly and other muscoid flies associated with poultry and livestock manure. N. C. Agric. Res. Serv. Tech. Bull. 278:1-88

136. Rutz, D. A., Axtell, R. C. 1978 . Factors affecting production of the mosquito Culex quinquefasciatus (= fatigans) from anaerobic animal waste lagoons. $N$. $C$. Agric. Exp. Stn. Tech. Bull. 256:1-32

137. Rutz, D. A., Axtell, R. C. 1979. Sustained releases of Muscidifurax raptor (Hymentoptera: Pteromalidae) for house fly (Musca domestica) control in two types of caged-layer poultry houses. Environ. Entomol. 8:1105-10

138. Rutz, D. A., Axtell, R. C. 1980 . House fly (Musca domestica) parasites (Hymenoptera: Pteromalidae) associated with poultry manure in North Carolina. Environ. Entomol. 9:175-80

139. Rutz, D. A., Axtell, R. C. 1981. House fly (Musca domestica) control in broilerbreeder poultry houses by pupal parasites (Hymenoptera: Pteromalidae): Indigenous parasite species and releases of Muscidifurax raptor. Environ. Entomol. 10:343-45

140. Rutz, D. A., Axtell, R. C., Edwards, T. D. 1980. Effects of organic pollution levels on aquatic insect abundance in field pilot-scale anaerobic animal waste lagoons. Mosq. News 40: 403-9

141. Rutz, D. A., Scoles, G. A. 1989. Occurrence and seasonal abundance of parasitoids attacking muscoid flies (Diptera: Muscidae) in caged-layer poultry facilities in New York Environ. Entomol. 18:51-55

142. Safrit, R. D., Axtell, R. C. 1984. Evaluations of sampling methods for darkling beetles (Alphitobius diaperinus) in the litter of turkey and broiler houses. Poult. Sci. 63:2368-75

143. Schmidtmann, E. T., Miller, R. W. 1984. Medical and veterinary, chickens: Gallus domesticus. Insecticide Acaricide Tests 9:552

144. Schmitz, M., Wohlgemuth, R. 1988. Untersuchungen zum Massenauftreten und Verhalten von Alphitobius diaperinus Panz. (Coleoptera, Tenebrionidae) in Hunermastbetrieben als Grundlage zur praxisgerechten Bekampfung.
Anz. Schaedlingskd. Pflanz. Umweltschutz 61:108-14

145. Schroeckenstein, D. C., Meier-Davis, S., Graziano, F. M., Falomo, A., Bush, R. K. 1988. Occupational sensitivity to Alphitobius diaperinus (Panzer) (lesser mealworm). $J$. Allergy Clin. Immunol. 82:1081-88

146. Scott, J. G., Rutz, D. A., Walcott, J. 1988. Comparative toxicity of seven insecticides to adult Spalangia cameroni Perkins. J. Agric. Entomol. 5:139-45

147. Shaaya, E. 1981. Sex pheromone of Dermestes maculatus DeGeer (Coleoptera, Dermestidae). J. Stored Prod. Res. 17:13-16

148. Sheppard, C. 1983. House fly and lesser house fly control utilizing the black soldier fly in manure management systems for caged laying hens. Environ. Entomol. 12:1439-42

149. Sheppard, M., Kissam, J. B. 1981. Integrated control of house flies on poultry farms: Treatment of house fly resting surfaces with diflubenzuron plus releases of the parasitoid, Muscidifurax raptor. J. Ga. Entomol. Soc. 16:222-27

150. Skidmore, P. 1985. The Biology of the Muscidae of the World. Dordrecht, Neth: W Junk

151. Stafford, K. C. III, Bay, D. E. 1987 Dispersion pattern and association of house fly, Musca domestica (Diptera: Muscidae), larvae and both sexes of Macrocheles muscaedomesticae (Acari: Macrochelidae) in response to poultry manure moisture, temperature, and accumulation. Environ. Entomol. 16: 159-64

152. Stafford, K. C. III, Collison, C. H. 1987. Manure pit temperatures and relative humidity of Pennsylvania high-rise poultry houses and their relationship to arthropod population development. Poult. Sci. 66:1603-11

153. Stafford, K. C. III, Collison, C. H., Burg, J. G. 1988. House fly (Diptera:Muscidae) monitoring method comparisons and seasonal trends in environmentally controlled high-rise, cagedlayer poultry houses. J. Econ. Entomol. 81:1426-30

154. Stafford, K. C. III, Collison, C. H., Burg, J. G., Cloud, J. A. 1988. Distribution and monitoring lesser mealworms, hide beetles, and other fauna in high-rise, caged-layer poultry houses. $J$. Agric. Entomol. 5:89-101

155. Stein, W., Gal, A., Gerneth, H. 1977. Zum Auftreten von Ophyra aenescens (Wiedemann) (Dipt., Muscidae) in Deutschland, Z. Angew, Zool, 64:311-24 156. Stockdale, H. J., Raun, E. S. 1960. 
Economic importance of the chicken louse. J. Econ. Entomol. 53:421-22

157. Swatonek, F. 1970. Zur Biologie des Glanzendschwarzen Getreideschimmelkafers (Alphitobius diaperinus Panz. = A. piceus Oliv.). Anz. Schaedlinskd. Pflanz. Unsweltschutz 43:101-4

158. Thornton, C. H. 1981. The effect of temperature on the growth and development of a South African strain of the hide beetle Dermestes maculatus Degeer (Coleoptera: Dermestidae). J. Entomol. Soc. South Afr. 44:343-49

159. Deleted in proof

160. Tseng, Y. L., Davidson, J. A., Menzer, R. E. 1971. Morphology and chemistry of the odoriferous gland of the lesser mealworm, Alphitobius diaperinus (Coleoptera: Tenebrionidae). Ann. Entomol. Soc, Am. 64:425-30

161. Turner, E. C. Jr. 1986. Structural and litter pests. Poult. Sci. 65:644-48

162. Ugochuku, E. I., Omije, F. A. 1986. Ectoparasitic fauna of poultry in Nsuk$\mathrm{ka}$, Nigeria. Int. J. Zoonoses 13:9397

163. USDA/FAS 1986. World Livestock and Poultry Situation. USDA For. Agric. Serv. Circ. FL\&PI-86

164. Vaughan, J. A., Turner, E. C. Jr. 1984. Residual and topical toxicity of various insecticides to the lesser mealworm (Coleoptera: Tenebrionidae). J. Econ. Entomol. 77:216-20

165. Vaughan, J. A., Turner, E. C. Jr., Ruszler, P. L. 1984. Infestation and damage of poultry house insulation by the lesser mealworm, Alphitobius diaperinus (Panzer). Poult. Sci. 63:1094-100

166. Warren, D. C., Eaton, R., Smith, H. 1948. Influence of infestations of bodylice on egg production in the hen. Poult. Sci. 27:641-42
167. Weaver, J. E., Kondo, V. A. 1987. Laboratory evaluation of insect growth regulators in producing lesser mealworm mortality and egg infertility. J. Agric. Entomol. 4:233-45

168. Weidhaas, D. E., Haile, D. G., Morgan, P. B., Labrecque, G. C. 1977 . A model to simulate control of housc flies with a pupal parasite, Spalangia endius. Environ. Entomol. 6:489-500

169. Williams, R. E., Hall, R. D., Broce, A. B., Scholl, P. J., eds. 1985. Livestock Entomology. New York: Wiley

170. Willis, R. R., Axtell, R. C. 1968 . Mite predators of the house fly: A comparison of Fuscuropoda vegetans and Macrocheles muscaedomesticae. J. Econ. Entomol. 61:1669-74

171. Wilson, T. H., Miner, F. D. 1979. Influence of temperature on development of the lesser mealworm, Alphitobius diaperinus (Coleoptera: Tenebrionidae). J. Kans. Entomol. Soc. 42:294 303

172. Wise, G. U., Hennessey, M. K., Axtell, R. C. 1988. A new species of manureinhabiting mite in the genus Poecilochirus (Âcari: Mesostigmata: Parasitidae) predacious on house fly eggs and larvae. Ann. Entomol. Soc. Am. 81: 209-24

173. Zeman, P., Stika, V., Skalka, B., Bartik, M., Lavickova, M. 1982. Potential role of Dermanyssus gallinae De Geer, 1778 in the circulation of the agent of pullurosis-typhus in hens. Folia Parasitol. 29:371-74

174. Zeman, P., Zelezny, J. 1985. The susceptibility of the poultry red mite, Dermanyssus gallinae (De Geer, 1778), to some acaricides under laboratory conditions. Exp. Appl. Acarol. 1:17-22 


\section{CONTENTS}

Sir Boris Uvarov (1889-1970): The Father of Acridology, $N$. Waloff and G. B. Popov

Scents and Eversible Scent Structures of Male Moths, $M$.

C. Birch, G. M. Poppy, and T. C. Baker

Superparasitism as an Adaptive Strategy for Insect

PaRAsItoids, Jacques J. M. van Alphen and Marcel E. Visser

Ecology and Management of the Colorado Potato Beetle, $J$. Daniel Hare

Ecology and Management of Arthropod Pests of Poultry, $R$. C. Axtell and J. J. Arends

Baculovirus Diversity and Molecular Biology, Gary $W$. Blissard and George F. Rohrmann

Ecology and Management of Sweet Potato Insects, Richard $B$. Chalfant, Richard K. Jansson, Dakshina R. Seal, and James M. Schalk

Evolution of Digestive Systems of Insects, Walter $R$. Terra

InSECt NeUROPEPTIDEs, G. Mark Holman, Ronald J. Nachman, and Mark S. Wright

The Midgut Ultrastructure of Hematophagous Insects, $P . F$. Billingsley

ENVIRONMENTAl INFluences on SoIl Macroarthropod Behavior IN Agricultural Systems, Michael G. Villani and Robert $J$. Wright

Properties and Potential of Natural Pesticides from the NeEm Tree, Azadirachta Indica, H. Schmutterer 
Arthropods and Other Invertebrates in Conservation-Tillage Agriculture, Benjamin R. Stinner and Garfield J. House

Evolution of Specialization in InSEct-Umbellifer Associations, May R. Berenbaum

Transmembrane Signalling In Insects, Sarah $C$. $R$. Lummis, Antony Galione, and Colin W. Taylor

The Changing Role of Extension Entomology in the IPM ERa, W. A. Allen and E. G. Rajotte

Epizootiological Models of Insect Diseases, $D . W$. Onstad and R. I. Carruthers

Ecological Genetics and Host adaptation in Herbivorous InSECTS: The Experimental Study of Evolution in Natural and Agricultural Systems, Sara Via

Searching Behavior Patterns in Insects, William J. Bell

Associations of Mites with Social Insects, George C. Eickwort 469

Population Biology of Planthoppers, Robert F. Denno and George K. Roderick

InTEgrated Suppression of Synanthropic Cockroaches, $C$. Schal and R. L. Hamilton

Epidemiology of Murine Typhus, A. F. Azad

Population Dynamics of Gypsy Moth in North America, $J . S$. Elkinton and A. M. Liebhold

Structure and Function of Insect Glia, Stanley D. Carlson and Richard L. Saint Marie

INDEXES

Subject Index

Cumulative Index of Contributing Authors, Volumes 26-35 631

Cumulative index of Chapter Titles, Volumes 26-35 